\title{
$\mathrm{Ti}$ 분말 첨가가 $\mathrm{TiO}_{2}$ 나노 분말의 성형성에 미치는 영향
}

\author{
박진섭 $\cdot$ 김효섭 $\cdot$ 이기석 ${ }^{a} \cdot$ 이정구 $^{b} \cdot$ 이창규 $^{b} \cdot$ 홍순직* $^{*}$
}

공주대학교 신소재공학부, 공주대학교 기계공학부, ${ }^{b}$ 한국원자력연구소

\section{The Effect of Ti Powder addition on Compaction Behavior of $\mathrm{TiO}_{2}$ Nano Powder}

\author{
Jin-Sub Park, Hyo-Seob Kim, Ki-Seok Lee ${ }^{a}$, Jeong-Goo Lee ${ }^{b}$, \\ Chang-Kyu Rhee ${ }^{b}$ and Soon-Jik Hong* \\ Division of Advanced Materials Engineering, Kongju National University, 275, \\ Budae-dong, Cheonan, Chungnam, 330-717, Korea \\ ${ }^{a}$ Division of Mechanical \& Automotive Engineering, Kongju National University, 275, \\ Budae-dong, Cheonan, Chungnam, 314-701, Korea \\ ${ }^{b}$ Nuclear Materials Research Division, Korea Atomic Energy Research Institute, \\ P.O. Box 105, Yuseong-Gu Daejeon, 305-353, Korea
}

(Received April 10, 2009; Revised April 30, 2009; Accepted May 8, 2009)

\begin{abstract}
The compaction response of $\mathrm{TiO}_{2}$ nano powders with an addition of Ti powders prepared by magnetic pulsed compaction and subsequent sintering processes was investigated. All kinds of different bulk exhibited an average shrinkage of about $12 \%$ for different MPCed pressure and sintering temperature, which were approximately $50 \%$ lower than those fabricated by general process $(20 \%)$ and a maximum density of around $92.7 \%$ was obtained for $0.8 \mathrm{GPa}$ MPCed pressure and $1400^{\circ} \mathrm{C}$ sintering temperature. The addition of Ti powder induced an increase in the formability and hardness of the sintered $\mathrm{TiO}_{2}$ But the lower densities were obtained on sintering with addition of over $10(\mathrm{wt} \%)$ Ti powder due to generation of crack during sintering. Subsequently it was verified that the optimum compaction pressure in MPC and sintering temperature were $0.8 \mathrm{GPa}$ and $1400^{\circ} \mathrm{C}$, respectively.
\end{abstract}

Keywords : Magnetic pulsed compaction, $\mathrm{TiO}_{2}$ nano powder, Ti powder, Densification, Shrinkage

\section{1. 서 론}

다양한 분야에 광범위하게 사용되고 있는 $\mathrm{TiO}_{2}$ 세 라믹 재료는 최근 $\mathrm{TiO}_{2}$ 분말을 소결하여 증착용 타 겟 재료로, 혹은 $\mathrm{HAP}, \mathrm{Ti}$ 등의 재료를 첨가하여 생 체재료로 활용하고 있는 추세이다. 일부 회사에서는 이미 이들 분말을 소결하여 제품화하고 있으나, 소결 과정에서 쉽게 형성되는 균열 문제와 치수 및 밀도 를 높이는 방안에 대한 지속적 연구가 필요한 상황 이다. 더욱 효과적인 소결기술을 확보하기 위해서는 무엇보다도 분말의 압축 성형기술에 의한 밀도의 향
상과 파괴인성 증가에 의한 신뢰도의 향상이 필요하 다. 세라믹 재료의 물성을 향상시키려면 소결 후에 결함을 제거하는 것이 중요하지만, 소결 후의 제어는 실제로 불가능하기 때문에 소결 이전의 공정인 분말 제조 및 성형공정에서의 제어가 중요하다[1-2]. 하지 만, 분말제조 과정에서는 입자형상 제어와 미세분말 제조의 제한사항때문에 더 많은 공정과 비용이 요구 되는 등 현재 많은 한계점을 가지고 있다[3].

또한, $\mathrm{TiO}_{2}$ 를 포함한 세라믹재료의 물성 대부분은 여러 가지 제조공정 및 성형 공정에 따라 크게 좌우 되므로, 이에 따른 공정기술의 개발은 실용화 측면에

*Corresponding Author : [Tel : +82-41-521-9387; E-mail : hongsj@kongju.ac.kr] 
서 큰 의의를 지니게 된다[4].

기존의 성형방법은 대부분 세라믹 미분말이 van der Waals나 그 밖의 다른 결합에 의한 응집입자를 함유하며, 충전과정에서의 입자간 마찰력 등에 의하 여 압분체의 성형밀도를 저하하여 고밀도의 성형이 불가능하고, 성형 시 불균일한 밀도 분포 때문에 쉽 게 파괴가 되어 효과적인 이용이 불가능하다는 문제 점이 있었다[5].

하지만, 최근 나노 금속 및 세라믹 분말의 성형 시 국부적인 성형을 억제하고 분말 전체에 일정한 힘 이 작용하며, 동시에 분말간의결합을 위해 운동에너지 를 효과적으로 투입할 수 있는 동적 성형방법인 자기 펄스 압축 성형(Magnetic Pulsed Compaction, MPC)
을 이용하면, 분말의 균일화 및 치밀화를 가능하게 하므로 고밀도의 성형체를 제작할 수 있고, 소결온도 를 낮출 수 있을 뿐만 아니라 높은 기계적 특성을 얻을 수 있는 특징이 있는 것으로 보고되고 있다[6]. 또한, 성형시간 단축과 자동화가 가능하여 기존의 일 반공정에 비해 경제성이 높은 장점을 가지고 있다.

본 연구에서는 이러한 장점이 보고된 자기펄스 압 축 성형법을 이용하여 $\mathrm{TiO}_{2}$ 나노분말의 치밀성을 개 선 시키고, 미량의 $\mathrm{Ti}$ 분말을 첨가함으로서 세라믹 재료에 인성을 부여할 수 있을 뿐만 아니라 미세조 직제어와 더불어 성형 및 소결 시 균열을 방지할 수 있을 것으로 기대된다. 이에 본 연구에서는 고속/고 압으로 우수한 성형성을 나타내는 자기펄스 압축 성

Table 1. Effect of different mixing conditions on the appearance of bulk at various compaction pressure and Ti powder (O: non crack, X: crack)

\begin{tabular}{|c|c|c|c|c|c|c|}
\hline No & Compaction pressure & $\operatorname{PVA}(g)+w(g)$ & $\mathrm{Tio}_{2}(\mathrm{~g})$ & Ti wt $\%$ & $\begin{array}{c}\text { Sintering Temperature } \\
(\mathrm{oC})\end{array}$ & Crack Formation \\
\hline 1 & $0.7 \mathrm{GPa}$ & $1+9$ & 40 & 2 & 1300 & $\mathrm{O}$ \\
\hline 2 & $0.7 \mathrm{GPa}$ & $1+9$ & 40 & 4 & 1300 & $\mathrm{O}$ \\
\hline 3 & $0.7 \mathrm{GPa}$ & $1+9$ & 40 & 6 & 1300 & $\mathrm{O}$ \\
\hline 4 & $0.7 \mathrm{GPa}$ & $1+9$ & 40 & 10 & 1300 & $\mathrm{O}$ \\
\hline 5 & $0.7 \mathrm{GPa}$ & $1+9$ & 40 & 20 & 1300 & $\mathrm{X}$ \\
\hline 6 & $0.7 \mathrm{GPa}$ & $1+9$ & 40 & 30 & 1300 & $\mathrm{X}$ \\
\hline 7 & $1 \mathrm{GPa}$ & $1+9$ & 40 & 0.5 & 1300 & $\mathrm{X}$ \\
\hline 8 & $1 \mathrm{GPa}$ & $1+9$ & 40 & 1 & 1300 & $\mathrm{X}$ \\
\hline 9 & $1.2 \mathrm{GPa}$ & $1+9$ & 40 & 2 & 1300 & $\mathrm{O}$ \\
\hline 10 & $1.2 \mathrm{GPa}$ & $1+9$ & 40 & 4 & 1300 & $\mathrm{O}$ \\
\hline 11 & $1.2 \mathrm{GPa}$ & $1+9$ & 40 & 6 & 1300 & $\mathrm{O}$ \\
\hline 12 & $1.5 \mathrm{GPa}$ & $1+9$ & 40 & 2 & 1300 & $\mathrm{O}$ \\
\hline 13 & $1.5 \mathrm{GPa}$ & $1+9$ & 40 & 4 & 1300 & $\mathrm{O}$ \\
\hline 14 & $1.5 \mathrm{GPa}$ & $1+9$ & 40 & 6 & 1300 & $\mathrm{O}$ \\
\hline 15 & $1.2 \mathrm{GPa}$ & $1+9$ & 40 & 10 & 1300 & $\mathrm{O}$ \\
\hline 16 & 1.2GPa & $1+9$ & 40 & 20 & 1300 & $\mathrm{X}$ \\
\hline 17 & 1.2GPa & $1+9$ & 40 & 30 & 1300 & $X$ \\
\hline 18 & $1.2 \mathrm{GPa}$ & $1+9$ & 40 & 40 & 1300 & $X$ \\
\hline 19 & 1.2GPa & $1+9$ & 40 & 50 & 1300 & $\mathrm{X}$ \\
\hline 20 & $1.7 \mathrm{GPa}$ & $1+9$ & 40 & 10 & 1300 & $X$ \\
\hline 21 & $1.7 \mathrm{GPa}$ & $1+9$ & 40 & 20 & 1300 & $X$ \\
\hline 22 & $1.7 \mathrm{GPa}$ & $1+9$ & 40 & 30 & 1300 & $\mathrm{X}$ \\
\hline 23 & $1.7 \mathrm{GPa}$ & $1+9$ & 40 & 40 & 1300 & $\mathrm{X}$ \\
\hline 24 & $1.7 \mathrm{GPa}$ & $1+9$ & 40 & 50 & 1300 & $\mathrm{X}$ \\
\hline 25 & $1.7 \mathrm{GPa}$ & $1+9$ & 40 & 0.5 & 1300 & $X$ \\
\hline 26 & $1.7 \mathrm{GPa}$ & $1+9$ & 40 & 1 & 1300 & $X$ \\
\hline
\end{tabular}


형장치를 이용하여 $\mathrm{TiO}_{2}+\mathrm{Ti}$ 혼합분말의 치밀화 거동 에 대한 연구를 수행하였으며, 성형압력과 소결온도 및 $\mathrm{Ti}$ 분말의 혼합비 변화에 따른 치밀화 거동과 기 계적특성에 대한 연구결과를 보고하고자 한다.

\section{2. 실험방법}

본 연구의 출발원료인 $\mathrm{TiO}_{2}$ 나노 분말은 국내 기 업으로부터 조달된 Rutile 형의 결정구조를 갖는 다 각형의 원료분말을 사용하였다. 일반적으로 세라믹 분말 자체로는 성형이 어려워 성형밀도의 증가와 성 형결함의 억제를 목적으로 binder를 첨가한다. 따라 서 본 연구에서는 $\mathrm{TiO}_{2}$ 나노 분말에 점결제로서 $\mathrm{PVA}$ 와 물을 사용하였으며 혼합 후 물은 $80^{\circ} \mathrm{C}$ 의 온 도에서 3시간 동안 건조하였다. 혼합량은 선행된 실 험의 결과값의 최적조건[6](PVA: $2 \mathrm{wt} \%$, 물: $18 \mathrm{wt} \%$ ) 에 $\mathrm{Ti}$ 분말을 $0.25 \sim 25 \mathrm{~g}$ 으로 다양하게 혼합하고, 자 기펄스 압축 성형장치를 이용하여 내경 $20 \mathrm{~mm}$ 의
금형에 $7 \mathrm{~g}$ 의 분말을 장입하여 판상의 디스크 형태 로 압축한 뒤 대기 중에서 소결하였다. 표 1 은 $\mathrm{TiO}_{2}$ 와 $\mathrm{Ti}$ 분말의 혼합비 및 압력변화에 대한 실험조건 을 나타내고 있으며, 표 2는 성형압력 및 소결 온도 변화에 따른 실험조건을 나타내고 있다.

본 연구에 사용된 자기펄스 압축 성형장치는 자기 펄스 형성부분, 가압펀치, 성형 몰드로 구성되어 있 으며, 최대 약 $4 \mathrm{GPa}$ 압력으로 300 마이크로초 내의 매우 짧은 시간에 초고압으로 성형할 수 있는 특징이 있다[7]. 실험 조건은 성형압력이 $0.7 \sim 1.7 \mathrm{GPa}, \mathrm{Ti}$ 혼 합비는 2 50 wt\%이었으며, 소결온도는 $1300 ~ 1400^{\circ} \mathrm{C}$ 에서 2 시간 동안 대기 중에서 상압소결을 하였다. 예 비 성형체의 밀도는 부피와 무게를 측정하여 계산하 였고, 소결체의 밀도는 아르키메데스 법으로 측정하 여 평균값으로 나타내었다. 제조된 소결체의 미세조 직은 전계방출 주사전자 현미경(Field Emission Scanning Electron Microscopy: FE-SEM)으로 관찰 하였으며, 소결체의 경도는 비커스 경도시험기를 이

Table 2. Effect of different mixing conditions on the appearance of bulk at various compaction pressure and sintering temperature (O: non crack, $\mathrm{X}$ : crack)

\begin{tabular}{ccccccc}
\hline \hline No & Compaction pressure & PVA $(\mathrm{g})+\mathrm{w}(\mathrm{g})$ & $\mathrm{Tio}_{2}(\mathrm{~g})$ & $\mathrm{Ti} \mathrm{wt} \%$ & $\begin{array}{c}\text { Sintering Temperature } \\
(\mathrm{oC})\end{array}$ & Crack Formation \\
\hline 1 & $0.7 \mathrm{GPa}$ & $1+9$ & 40 & 2 & 1350 & $\mathrm{O}$ \\
2 & $0.7 \mathrm{GPa}$ & $1+9$ & 40 & 4 & 1350 & $\mathrm{O}$ \\
3 & $0.7 \mathrm{GPa}$ & $1+9$ & 40 & 6 & 1350 & $\mathrm{O}$ \\
4 & $0.8 \mathrm{GPa}$ & $1+9$ & 40 & 2 & 1350 & $\mathrm{O}$ \\
5 & $0.8 \mathrm{GPa}$ & $1+9$ & 40 & 4 & 1350 & $\mathrm{O}$ \\
6 & $0.8 \mathrm{GPa}$ & $1+9$ & 40 & 6 & 1350 & $\mathrm{O}$ \\
7 & $0.9 \mathrm{GPa}$ & $1+9$ & 40 & 2 & 1350 & $\mathrm{O}$ \\
8 & $0.9 \mathrm{GPa}$ & $1+9$ & 40 & 4 & 1350 & $\mathrm{O}$ \\
9 & $0.9 \mathrm{GPa}$ & $1+9$ & 40 & 6 & 1350 & $\mathrm{O}$ \\
10 & $0.7 \mathrm{GPa}$ & $1+9$ & 40 & 0 & 1400 & $\mathrm{O}$ \\
11 & $0.8 \mathrm{GPa}$ & $1+9$ & 40 & 0 & 1400 & $\mathrm{O}$ \\
12 & $0.9 \mathrm{GPa}$ & $1+9$ & 40 & 0 & 1400 & $\mathrm{O}$ \\
13 & $0.7 \mathrm{GPa}$ & $1+9$ & 40 & 2 & 1400 & $\mathrm{O}$ \\
14 & $0.7 \mathrm{GPa}$ & $1+9$ & 40 & 4 & 1400 & $\mathrm{O}$ \\
15 & $0.7 \mathrm{GPa}$ & $1+9$ & 40 & 6 & 1400 & $\mathrm{O}$ \\
16 & $0.8 \mathrm{GPa}$ & $1+9$ & 40 & 2 & 1400 & $\mathrm{O}$ \\
17 & $0.8 \mathrm{GPa}$ & $1+9$ & 40 & 4 & 1400 & $\mathrm{O}$ \\
18 & $0.8 \mathrm{GPa}$ & $1+9$ & 40 & 6 & 1400 & $\mathrm{O}$ \\
19 & $0.9 \mathrm{GPa}$ & $1+9$ & 40 & 2 & 1400 & $\mathrm{O}$ \\
20 & $0.9 \mathrm{GPa}$ & $1+9$ & 40 & 6 & 1400 & 1400 \\
21 & $0.9 \mathrm{GPa}$ & & & & \\
\hline
\end{tabular}


용하여 측정하였다.

\section{3. 결과 및 고찰}

그림 1 은 성형에 이용된 $\mathrm{TiO}_{2}$ 나노 분말 및 $\mathrm{Ti}$ 분말 입자 크기와 형상을 나타내는 주사전자현미경 사진(SEM)으로서 $\mathrm{TiO}_{2}$ 나노 분말은 $100 \sim 300 \mathrm{~nm}$ 크기로 분말입자들이 응집되어 있는 형태를 나타냈 으며, 나노 분말의 표면에서 그 밖의 다른 불순물은 관찰되지 않았다. 또한, 혼합분말로 사용된 $\mathrm{Ti}$ 분말 은 구형의 형상으로 분말입자의 크기는 $20 \sim 50 \mu \mathrm{m}$ 를 나타냈다.

세라믹 나노 분말은 앞서 말한 바와 같이 수분과 함께 점결제 없이는 초기 성형이 어려우므로 본 연 구에서는 실험조건(표 1 , 표 2)에 나타낸 것과 같이 $\mathrm{TiO}_{2}$ 분말에 PVA와 물을 점결제로 사용하고, $\mathrm{Ti}$ 분 말의 함량을 다양하게 변화시켜 최적의 혼합조건을 확립하고자 하였다. 표 1 의 균열형성 여부에서 볼 수 있는 것과 같이 $\mathrm{Ti}$ 함량이 $2-10 \%$ 범위에서는 예비

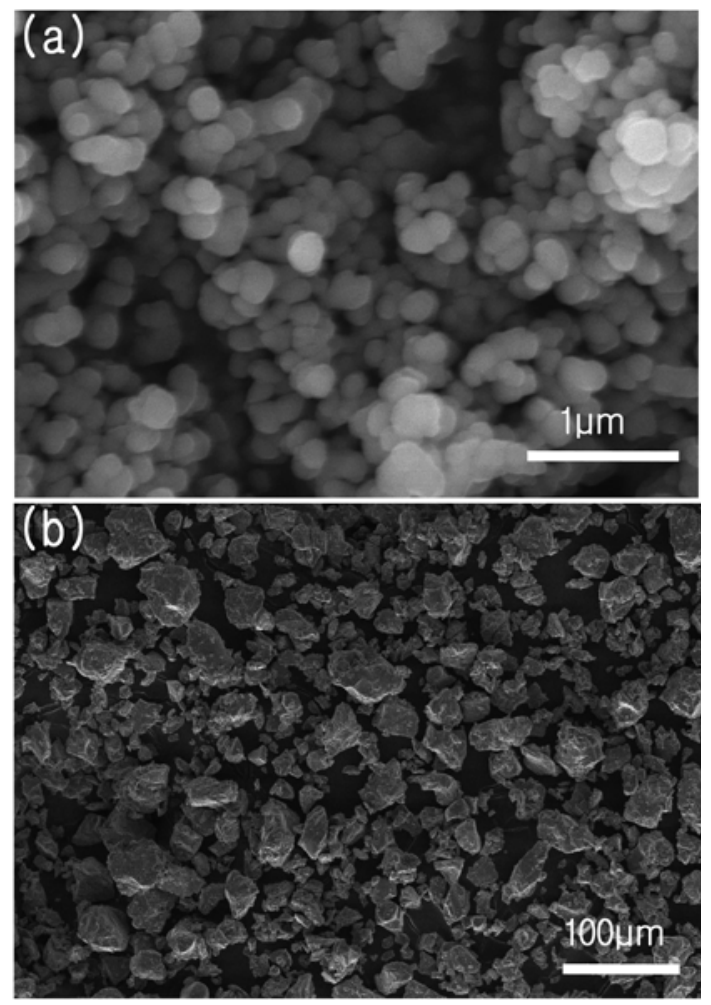

Fig. 1. SEM micrographs of (a) $\mathrm{TiO}_{2}$ nano powder and (b) Ti Powder.
성형체에서 균열이 형성되지 않았으나 그 외의 조건 에서는 균열이 형성됨을 알 수 있었다. 또한, 표 2에 서 볼 수 있는 것과 같이 $\mathrm{Ti}$ 함량을 $2-6 \%$ 로 고정하 고, 압력과 소결온도를 변화시켜서 성형한 결과 모든 시료에서 균열이 관찰되지 않았다.

그림 2는 자기펄스 압축 성형장치로 성형압력변화 $(0.7 \sim 1.7 \mathrm{GPa})$ 와 $\mathrm{Ti}$ 분말의 혼합비율 $(2 \sim 50 \mathrm{wt} \%)$ 을 달 리 하였을 때 각 조건에 따른 파괴경향을 나타내고 있다. 같은 $\mathrm{TiO}_{2}$ 와 점결제 혼합조건에서 $\mathrm{Ti}$ 의 혼합비 가 증가함에 따라 성형압력도 점차 증가하여 10 $\mathrm{wt} \%$ 이상에서는 $1.2 \mathrm{GPa}$ 이상의 압력에서도 균열이 없는 성형체를 제조할 수 있었다. 그러나 소결 후 $0.9 \mathrm{GPa}$ 이상의 압력으로 성형된 모든 시료에서 심한 균열이 형성되어 밀도가 감소하였다. 이와 같은 결과 는 높은 성형압력 때문에 세라믹 재료의 압축 - 성형 시 성형체 내부에 과도한 탄성 에너지가 축적되고,
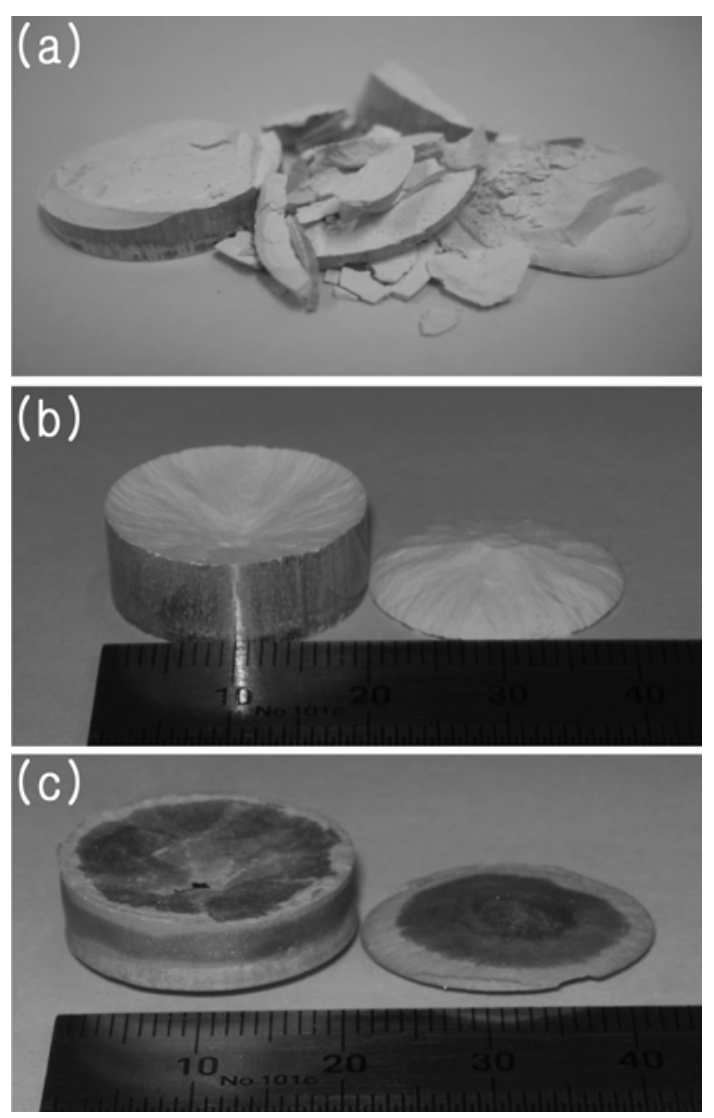

Fig. 2. Photos of fracture behavior of $(a, b)$ MPCed components and sintered and (c) bulk. 


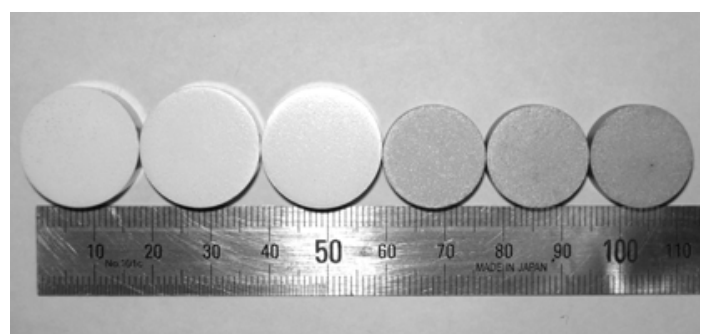

Fig. 3. Photo of comparing size and shape of (left) MPCed component $(0.7 \mathrm{Gpa})$ and find component with (right) MPC ((0.7GPa)+sintering).

이러한 탄성에너지가 분말의 치밀화에 필요한 에너 지를 초과하여 소결 시 균열이 발생하는 것으로 판 단된다[6]. 또한, $\mathrm{Ti}$ 분말의 혼합비 증가에 따른 예비 성형체에서의 성형압력 증가는 $\mathrm{Ti}$ 분말을 첨가함으로 서 압축 - 성형 시 소셩변형이 좀 더 용이하고 과도 한 탄성에너지의 축적을 방지하는 역할을 하였기 때 문인 것으로 생각된다. 하지만 그림 2(c)에 보이는 바와 같이 $\mathrm{Ti}$ 혼합비가 $10 \mathrm{wt} \%$ 이상에서는 높은 소 결온도에 의해 성형체 내부의 $\mathrm{Ti}$ 분말이 용융상태에 가까워 짐으로서 중심 쪽으로 Ti가 유동하면서 최종 소결체의 형상이 변형되거나 심한 균열을 일으키는 현상을 관찰할 수 있었다. 이와 같은 결과는 $\mathrm{Ti}$ 혼합 비가 증가할수록 더욱 심하게 일어났다. 결과적으로 $\mathrm{Ti}$ 분말의 혼합비 증가는 성형체의 성형성은 증가시 키지만 $10 \mathrm{wt} \%$ 이상에서는 오히려 소결 시 변형이 나 균열을 일으켜 최종 소결체의 밀도를 저하하는 원 인이 됨을 알 수 있었다.

그림 3 은 $\mathrm{TiO}_{2}+\mathrm{Ti}$ 혼합 분말을 $20 \mathrm{~mm}$ 지름의 금형에 주입하고 자기펄스 압축 성형장치로 성형한 초기 성형체와 이를 $1400^{\circ} \mathrm{C}$ 에서 2 시간 동안 소결시 킨 소결체를 나타내는 사진으로써 소결체 표면에서 는 어떠한 결함이나 균열이 관찰되지 않았다. 초기성 형체는 지름이 $20 \mathrm{~mm}$ 높이가 $9.27 \mathrm{~mm}$ 이었으며, 소결후에는 지름이 $17.2 \mathrm{~mm}$ 높이가 $8 \mathrm{~mm}$ 로 감소 하였다. 자기펄스 압축 성형 장치로 $0.7 \sim 0.9 \mathrm{GPa}$ 의 압력으로 성형하여 $1400^{\circ} \mathrm{C}$ 에서 2시간 동안 유지하였 을 때 $\mathrm{Ti}$ 분말의 혼합비 변화 $(2 \sim 30 \mathrm{wt} \%)$ 에 따라 균열이 발생한 경우를 제외하고 수축률은 평균 약 $10 \%$ 로 나타났다. 이와 같은 수축률은 기존의 일반공 정 $(20 \%)$ 보다 $50 \%$ 정도 낮은 값으로써 최종제품의 소 결 시 균열을 방지하고 치수정밀도를 향상시킬 수 있

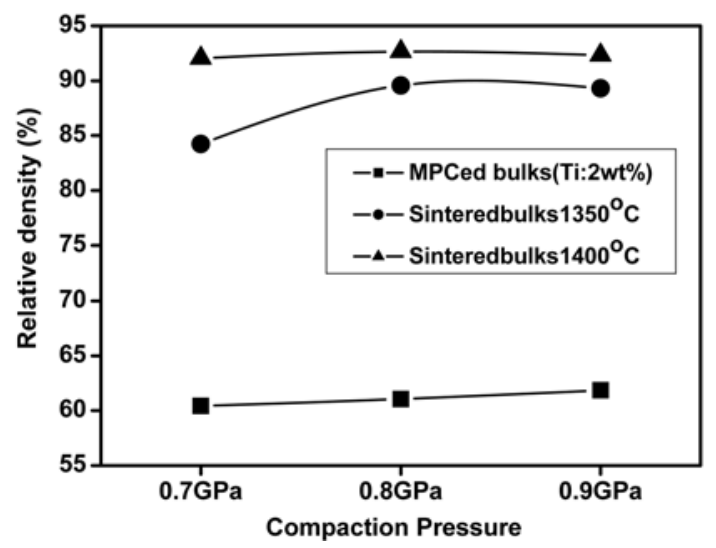

Fig. 4. Variation of relative densities for the MPCed $\mathrm{TiO}_{2}+\mathrm{Ti}$ pre-compacts and then sintered bulks prepared at different conditions of MPC pressure and sintering temperatures.

을 것으로 기대된다. 많은 연구결과에서 상압소결에 서 소결특성을 저하하는 원인으로 나노 분말 자체의 응집경향과 불균일 성형 미세구조, 특히 불균일 기공 구조를 지적하고 있다[8-9]. 따라서 자기펄스 압축 성 형장치를 이용하여 성형하고 소결하는 경우 나타나 는 이러한 낮은 수축률은 높은 성형압력 때문에 일 반공정보다 입자충전 미세구조의 균일도 향상 및 내 부기공의 감소로 초기성형체의 높은 치밀화를 이루 어 소결특성이 향상된 것으로 생각된다.

그림 4는 자기펄스 압축 성형장치로 성형한 초기 성형체와 이를 $1350,1400^{\circ} \mathrm{C}$ 에서 2 시간 동안 각각 소결하였을 때의 밀도변화를 나타내고 있다. 그림에 서 볼 수 있는 것과 같이 초기성형체의 밀도는 평균 $60 \%$ 로 일반 공정[10-11]에 비해 매우 높은 결과를 나타내고 있으며, 소결 후 평균밀도 $90 \%$ 이상으로서 짧은 소결 시간에도 불구하고 높은 밀도분포를 나타 냈다. 일반적으로 $90 \%$ 이상의 소결밀도를 얻기 위해 서는 일반공정은 많은 요인에 의해 고압성형이 어려 우므로 낮은 압력으로 성형하여 장시간의 소결을 필 요로한다. 하지만 자기펄스 압축 성형장치는 빠른 속 도와 압력에 의한 초기 성형체의 미세구조의 균일화 및 높은 치밀화로 인한 내부기공의 감소와 높은 에 너지에 의한 소결 구동력의 향상에 의해 2 시간의 짧 은 소결시간으로도 약 $90 \%$ 이상의 높은 소결 밀도 를 얻을 수 있는 것으로 판단된다.

그림 5 는 $\mathrm{Ti}$ 혼합비에 따라 자기펄스 압축 성형장 


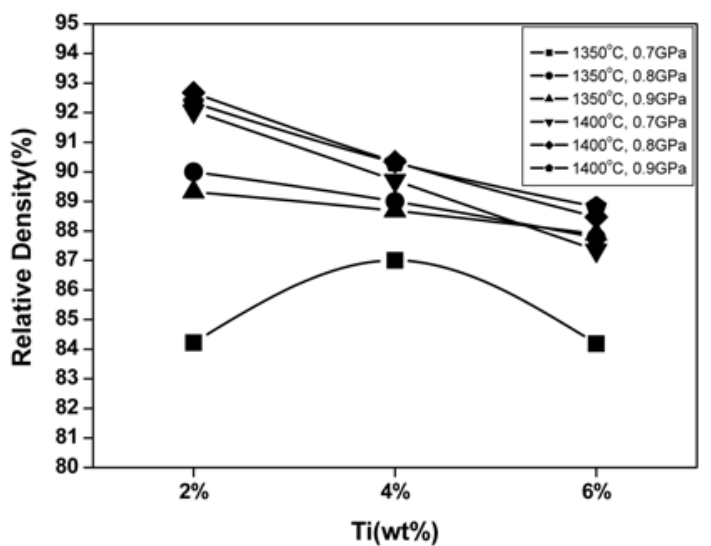

Fig. 5. Relative density as a function of $\mathrm{Ti}$ with powder addition at various MPCed pressure and sintering temperatures.

치로 압축하고 $1400^{\circ} \mathrm{C}$ 에서 2 시간 동안 소결된 소결 체의 밀도 변화를 나타낸 그래프이다. 일반적으로 세 라믹분말의 소결특성 및 최종밀도에 영향을 주는 주 된 인자는 소결온도와 성형압력 및 첨가제 등으로 알 려져 있다[10]. 본 연구에서는 실질적인 치밀화는 $1000^{\circ} \mathrm{C}$ 이상에서 일어났으며, 온도상승과 더불어 소 결밀도는 증가하여 $1400^{\circ} \mathrm{C}$ 2시간에서 최대값을 나타 내다가 이후 온도에서는 큰 변화가 없었기때문에 최 적의 소결온도는 $1400^{\circ} \mathrm{C}$ 부근임을 알 수 있었다. 또 한, 압축압력이 증가함에 따라 밀도는 증가하였고, $0.7 \sim 0.9 \mathrm{GPa}$ 의 성형압력에서 균열이 없는 성형체 및 소결체를 제조할 수 있었다. Ti의 혼합비는 증가할수 록 성형성은 증가시켰지만, 최종 소결체의 밀도 및 수축률은 감소하였다. 일반적으로 세라믹 분말의 소 결 시 첨가제를 넣는 이유는 소결체의 최종 밀도를 증가시키기 위함이지만, 밀도 이외의 소결특성이나 기계적특성을 요구하는 경우에는 약간의 밀도저하를 감수하더라도 첨가제의 사용은 필수적이다. 하지만, 실험결과에서도 알 수 있듯이 $\mathrm{Ti}$ 첨가 시 밀도는 감 소하였지만 그 차이가 $1 \%$ 미만으로 $\mathrm{Ti}$ 첨가에 의한 소결밀도 저하는 크지 않은 것으로 판단된다.

그림 6 은 초기 자기펄스 압축압력 변화에 따른 소 결체의 지름과 높이 수축률을 나타내는 것으로서 그 림에서 볼 수 있는 것과 같이 $\mathrm{Ti}$ 의 혼합비가 증가함 에 따라 수직 및 수평 방향 모두 수축률이 약간 감 소하였지만 평균 약 $10 \%$ 로 거의 일정한 값을 나타 내었다. 이와 같은 결과는 기존공정 $(20 \%)$ 에 비해

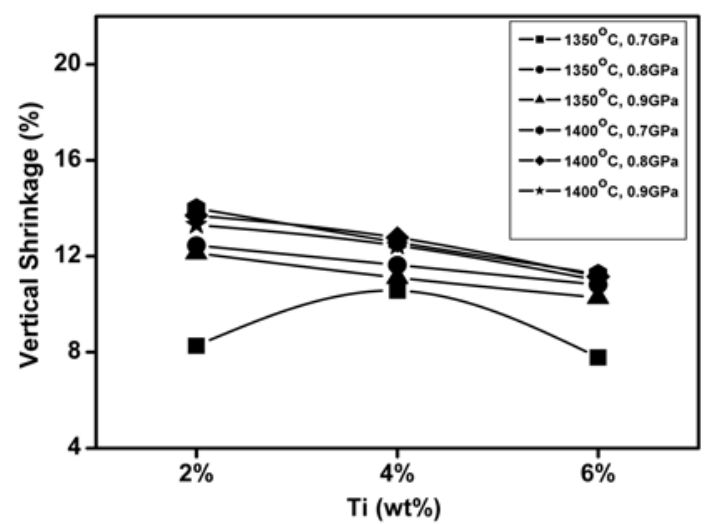

(a)

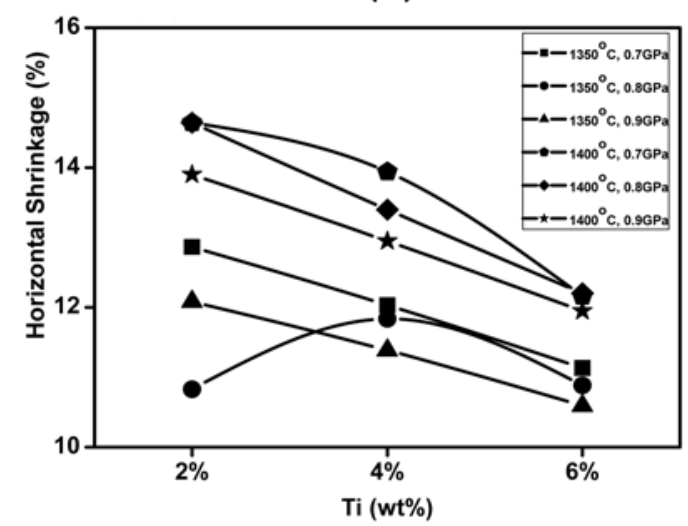

(b)

Fig. 6. (a) Vertical and (b) Horizontal shrinkage of sintered (MPC+sintering) bulks at different MPC pressure and sintering temperatures.

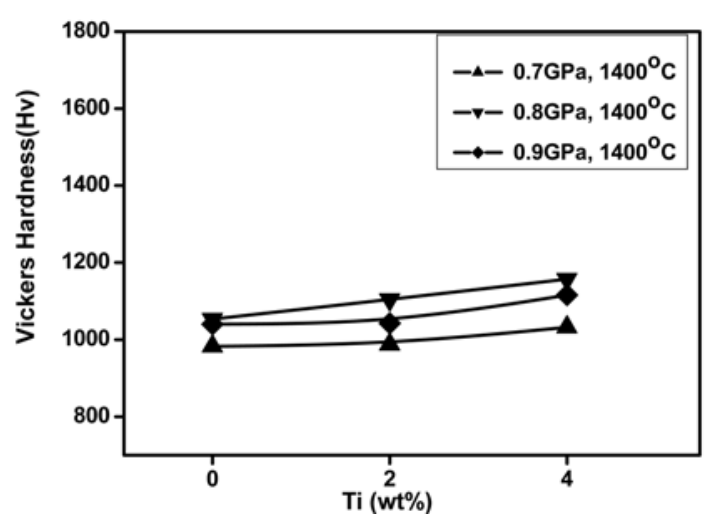

Fig. 7. Vickers Hardness of sintered bulks (MPC+sintering) at $1400^{\circ} \mathrm{C}$ for $2 \mathrm{~h}$ as a function of different mixing conditions.

$50 \%$ 정도 낮은 값으로서 자기펄스 압축 성형장치로 짧은 시간에 매우 높은 압력으로 인해 치밀화가 증 
가하여 소결 후에도 수축률이 큰 변화가 없는 것으 로 생각된다. 또한, 수직 및 수평 방향의 수축률이 모두 일정한 값으로 기존 성형 공정과는 달리 치수 제어에 매우 유리할 것으로 기대된다.

그림 7은 $\mathrm{Ti}$ 혼합비 및 자기펄스 압축 성형 압력 변화에 따라 성형 후 소결된 소결체의 경도변화를 나 타내고 있다. 그림에서 볼 수 있는 것과 같이 $\mathrm{Ti}$ 의 혼 합비가 증가할수록 경도 값 역시 증가함을 알 수 있었 다. 경도 향상에 영향을 미치는 인자로는 소결성, 결정 립 크기, 내부 기공률 등이 있으며[12], 본 실험의 결 과 성형 및 소결조건이 동일하였기 때문에 $\mathrm{Ti}$ 를 혼합 한 소결체가 일반 소결체에 비해 높은 경도를 나타내 는 것은 $\mathrm{Ti}$ 혼합에 의해 이들 인자에 특별한 영향을 미침으로써 경도값이 향상된 것으로 보인다. 이에 대 한 자세한 연구는 미세조직 및 기계적 특성 분석을 통 하여 정확한 원인을 해석할 수 있을것으로 생각된다.

소결된 세라믹재료는 취성이 강하기 때문에 많은 연구자가 경도시험을 이용하여 파괴 인성을 계산하
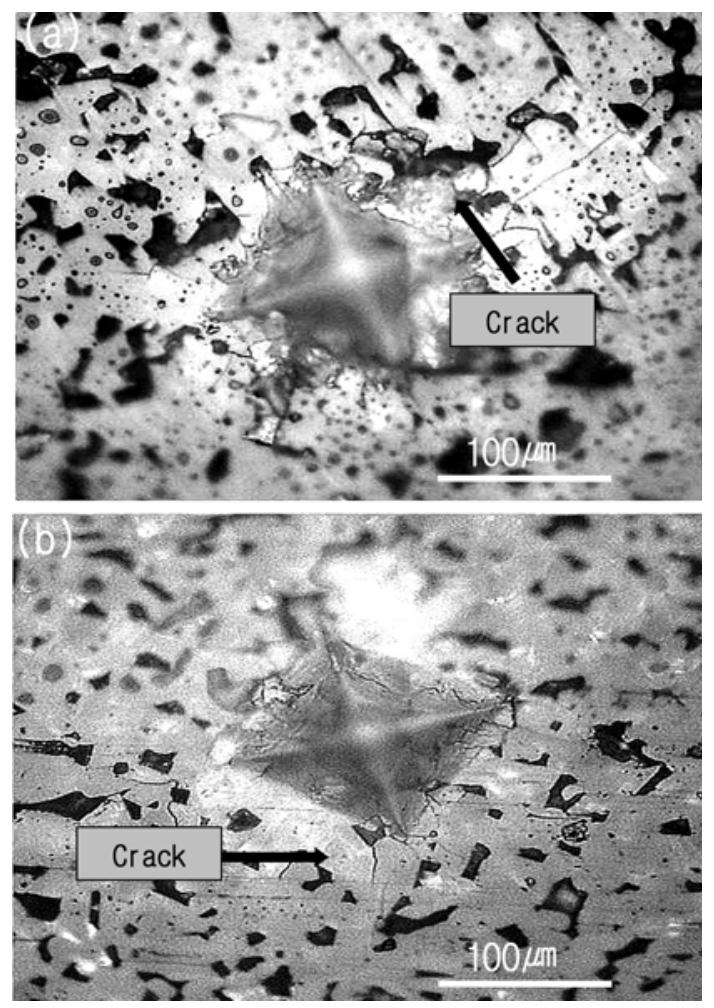

Fig. 8. Optical micrographs of sintered (a) $\mathrm{TiO}_{2}$ and (b) $\mathrm{TiO}_{2}+\mathrm{Ti}$ bulks with different preparation condition showing cracks formed from the corners of hardness indenters.

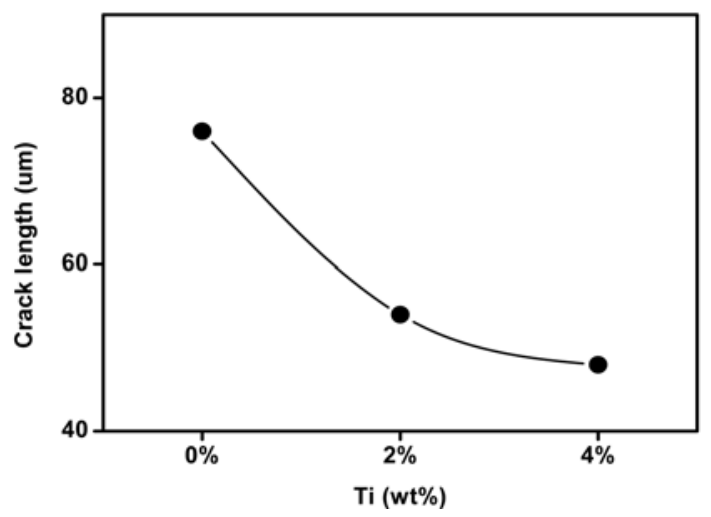

Fig. 9. Showing different crack length of sintered bulks at $0.8 \mathrm{GPa}, 1400^{\circ} \mathrm{C}$ for $2 \mathrm{~h}$ as a function of different mixing conditions.

는 연구결과를 보고하고 있으나 본 연구에서는 이에 대한 정확성을 고려하여 파괴 인성 값은 계산하지 않 았으며, 단지 측정 후 형성된 압흔자 주위를 광학현 미경으로 관찰하여 균열 형성 및 길이를 측정하여 그 결과를 그림 8 과 9 에 각각 나타냈다. 그림 $8(\mathrm{a})$ 는 $\mathrm{Ti}$ 분말을 첨가하지 않고, 성형 및 소결된 $\mathrm{TiO}_{2}$ 나노 분말 소결체의 압흔자 주위에서 형성된 균열을 나타 내는 사진으로 균열의 크기는 $77 \mu \mathrm{m}$ 길이를 가지고 있음을 알 수 있다. 그러나 같은 성형 조건에서 $\mathrm{Ti}$ 분말이 첨가된 소결체의 경우(그림 8(b), Ti $4 \mathrm{wt} \%$ ) 는 순수한 $\mathrm{TiO}_{2}$ 나노 분말 소결체보다 균열 길이가 $20 \mu \mathrm{m}$ 로 짧음을 알 수 있었다. 이처럼 $\mathrm{Ti}$ 분말 함 량 변화에 따라 소결된 소결체의 경도 및 균열 길이 측정 결과를 그림 7과 9에 각각 나타냈다. 경도와 균열 길이는 5 회의 측정결과를 평균으로 계산하였으 며, 그림 7과 9에서 볼 수 있는 것과 같이 $\mathrm{Ti}$ 첨가 량이 $2 \%, 4 \%$ 로 증가함에 따라 경도는 각각 $50 \mathrm{Hv}$ 씩 증가하였으며, 균열 길이는 $30 \mu \mathrm{m}, 10 \mu \mathrm{m}$ 씩 감 소하였다. 이와 같은 결과는 $\mathrm{TiO}_{2}$ 나노 분말 소결에 순수한 $\mathrm{Ti}$ 분말 첨가에 의하여 최종 소결체의 밀도 저하 없이 경도를 증가시키고, 균열 전파를 줄여서 기계적 특성 향상에 효과가 있는 것으로 생각된다. 또한, 적합한 첨가제의 비율 조절에 의하여 요구하는 특성을 개선할 수 있을 것으로 기대된다.

\section{4. 결 론}

본 연구에서는 자기펄스 압축 성형장치를 이용하 
여 $\mathrm{TiO}_{2}+\mathrm{Ti}$ 혼합 분말의 성형 및 소결체의 치밀화 거동과 기계적 특성에 대한 연구를 수행하였다. 성형 압력이 $0.7 \sim 0.9 \mathrm{GPa}$, 소결온도가 $1400^{\circ} \mathrm{C}, \mathrm{Ti}$ 혼합비 가 2 6 wt\%일 때 변형 및 균열이 없는 소결체를 얻 을 수 있었으며, 이때 최대밀도는 이론 밀도의 약 $92.7 \%$ 를 나타내었다. 성형압력 변화에 따른 소결체 의 수축률은 가로 및 세로가 평균적으로 $10 \%$ 의 범 위를 나타내었으며, 이와 같은 값은 일반 공정 $(20 \%)$ 에 비해 $50 \%$ 낮은 비율로서 성형 및 소결 시 균열 방지와 치수조절에 더 나은 성형방법임을 알 수 있 었다. 또한, $\mathrm{Ti}$ 의 혼합비 변화는 성형성의 증가 및 균열 방지 그리고 최종 소결체의 인성 증가와 같은 효과를 나타내었으며, 과도한 첨가량은 오히려 소결 과정에서 소결체의 변형이나 균열을 일으킬 수 있으 므로 $10 \mathrm{wt} \%$ 이내로 사용하여야 함을 알 수 있었다. 결과적으로 자기펄스 압축 성형장치를 이용하여 $\mathrm{Ti}$ 분말 첨가에 따른 $\mathrm{TiO}_{2}$ 나노 분말의 치밀화 및 기계 적특성(파괴인성)의 개선의 가능성을 확인하였으며, 성형압력, 소결온도, $\mathrm{Ti}$ 및 점결제의 혼합비 등과 같 은 최적의 성형 조건을 확립함으로써 기존 공정보다 우수한 밀도와 특성이 있는 $\mathrm{TiO}_{2}$ 소결체 제조가 가 능할 것으로 기대된다.

\section{감사의 글}

본 연구는 산업자원부의 21 세기 프론티어 연구개
발사업의 일환인 “차세대 소재성형기술개발 사업단” 의 연구비 지원으로 수행되었습니다. 이에 감사드립 니다.

\section{참고문헌}

[1] J. H. Song, J. S. Lee, I. S. Park and D. Y. Lim: J. Kor. Ceram. Soc., 37 (2000) 625 (Korean).

[2] G. H. Lee and C. K. Rhee: J. Kor. Inst. Met. \& Mater., 9 (2003) 425.

[3] J. H. Song, J. S. Lee, I. S. Park and D. Y. Lim: J. Kor. Ceram. Soc., 37 (2000) 625 (Korean).

[4] A. Kumpmann, B. Gnther and H. D. Kunze, Mater. Sci. Eng. A., 168 (1993) 165.

[5] H. C. Park and Frank L. Riley: J. Kor. Ceram. Soc., 29 (1992) 489 (Korean).

[6] H. S. Kim, J. G. Lee, C. K. Rhee, J. M. Koo and S. J. Hong: J. Kor. Mater. Res, 18 (2008) 8 (Korean).

[7] R. C. Kang, M. K. Lee, W. W. Kim, C. K. Rhee and S. J. Hong: J. Kor. Powder Metall. Inst., 15 (2008) 38 (Korean).

[8] W. H. Rhodes: J. Am. Ceram. Soc., 64 (1981) 19.

[9] F. W. Dynys and J. W. Halloran: J. Am. Ceram. Soc., 67 (1984) 596.

[10] Y. L. Chen and R. J. Brook, Br: J. Ceram. Trans., 88 (1989) 7.

[11] Mehdi Mazaheri, A. M. Zahedi, M. Haghighatzadeh and S. K. Sadrnezhaad: Ceram. Int., 35 (2009) 685.

[12] J. H. Shin, Y. G. Jung and S. K. Hur: J. Ceram. Soc., 37 (2000) 856. 